\title{
AN EVANESCENT BOOK
}

\author{
The gift of knowledge.
}

\section{BY TITO URETA}

A recension of the Book of Sand ANONYMOUS, DESCRIBED BY JORGE LUIS BORGES, ALIANZA EDITORIAL BUENOS AIRES 1977.

Quantum Foam Holographic Publishers, London, 2031. Quantumholographic edition. $\infty p p$.

$\mathrm{F}$ rom about 2030 onwards there were rumours that a group of librarians had finally found the Book of Sand, which Jorge Luis Borges purposely lost (among maps and periodicals) in the cavernous depths of the National Library in Buenos Aires. As will be remembered, the book contains an infinite number of pages, none of them being the first and none being the last. Even though Borges did not say so explicitly, several scholars have attributed the unbounded vastness of this mythical book to the fact that it is the repository of all knowledge, in the form of an encyclopaedia with pages that divide and subdivide without limit. When Borges examined the book, the World-Wide Web did not exist but his description is quite clear. The Book of Sand is not the Web as it is truthful, non-profit, non-redundant and garbage-free.

The Book of Sand has indeed been found and it is now available for examination. It is certainly impossible to produce a facsimile or a digital version with conventional techniques, as the content of the book is infinite and the digitization would require a computer with infinite memory. Nevertheless, with a newly described technique whose scientific basis eludes me, known as Quantum Foam Holographic Scanning, it is now possible to produce a hologram that can be perused in the same way as if the original were in your hands.

Everything that Borges said about the Book of Sand is true. Like him, I tried to open the first or the last page, but no matter what I tried a few pages inevitably appeared between the cover and my fingers. If I opened it at random I always found two facing pages of entries, some of them with pictures, as in a conventional encyclopaedia.
Because of my professional bias I was delighted to find an entry labelled 'DNA'. It begins with a description of Miescher's experiments, followed by those of Griffiths (without mentioning the names of the scientists), but on reaching the bottom line and attempting to turn the page, I found myself in front of a page describing the adventures of a medieval gentleman named Durandarte. When I tried to go back to the previous page I found that it was no longer possible.

I wonder about those pages that I can no longer find. Of course the enormous discovery by Avery, the telling findings of Chargaff, the fecund model of Crick and Watson, and the Genome Project of the end of the last century must all be there, and, maybe, the base sequences of the 300,000 genomes now in the databases (from all creatures living and extinct?) and surely the current research on extragalactic DNA. I am sure that all that is displayed in the pages between DNA and Durandarte but the probability of opening one of them is

\section{DNATURE.COM}

Follow Futures on Facebook at:

go.nature.com/mtoodm vanishingly small, and if I get close I shall perhaps find a passage about Donosti- 웍 arra or the love potions of a scoundrel called Dulcamara. Perhaps - horror! - only very long and very boring series of purines and pyrimidines in a list like TTTGGTCAGATGGCATTGGG ... from an organism whose name appears in a page that I cannot visit.

The Book of Sand is, then, a mirror of our world. We use all our senses trying to make sense of it. But the world, like the Book of Sand, allows us only to retrieve, per speculum et in aenigmate, mere bits that only rarely give us the certainties that we need.

Thus the Book of Sand is a complete, and at the same time a partial, encyclopaedia with pages that can offer only fragments. But it is infuriating to know that the encyclopaedia is, in fact, complete and that all the present and future knowledge is there, if only one could turn the pages in the proper sequence. Alas! the book is a sandbook and it is therefore impossible to do that.

But then, it might be better that way. If I could read the Book of Sand as an ordinary encyclopaedia, it would no longer be worthwhile to continue my ongoing research on the molecular dictionaries of the Nostratic language. If I could find in the Book of Sand the appropriate paragraphs, I would know today all about the molecular structure of the grammars stored in the brain and, therefore, all the fun of pursuing my investigations on that marvellous area would be gone for ever. It was indeed a wise man who said that the path contains the goal and that the goal cannot exist without the path.

So I have closed my hologram copy of the Book of Sand and put it on a nearby shelf. Who knows? From time to time I shall open it at random and maybe I shall find some nuggets that shed light on my questions.

Tito Ureta is a professor in the Departamento de Biología, Facultad de Ciencias, Universidad de Chile, Santiago de Chile. 